\title{
Chili Cultivation Technique Using Fermentation of Liquid Organic Fertilizer as Catfish Waste Utilization in Tasik Madu Village, Merbau Mataram
}

\author{
Mahfut dan Yulianty \\ Jurusan Biologi, Fakultas MIPA Universitas Lampung. Lampung. 35145) \\ Correspondence: ${ }^{1}$ mahfutkariem@yahoo.com / mahfut.mipa@fmipa.unila.ac.id; \\ 2yoelisoeradji@yahoo.co.id
}

Diterima 23 Juni 2019 , Disetujui 25 November 2019 Dipublikasikan 30 November 2019

\begin{abstract}
Chili (Capsicum annuum L.) is a plant that belongs to the family Solanaceae. In addition to catfish cultivation, chilli cultivation is also a superior product program for Sumber Rejeki II Farmers Group, Tasik Madu Hamlet, Talang Jawa Village, Merbau District, Mataram. The use of fertilizer by residents in the cultivation of chili plants is limited to using manure at the beginning of planting and chemical fertilizer as an addition. Information on making fermented liquid organic fertilizer using the utilization of organic waste from pond water consumed by catfish consumption is very beneficial for Sumber Rejeki II Farmers Group because the application of organic liquid fertilizer is very effective in growing chili plants and can reduce production costs. The Community Service Program (PKM) DIPA BLU Junior University of Lampung in 2017 was carried out in three stages, namely; counseling, training, and mentoring through partnerships with one of the residents, Chairman of Sumber Mulya Farm, Mr. Muslim. The results obtained in counseling as an initial activity is an increase in participant knowledge about the manufacture of liquid organic fertilizer fermented from catfish pond waste. The end result of this PKM program is the application of the utilization of catfish cultivation waste in the maintenance and increase of chili crop production.
\end{abstract}

Keywords: chili, organic fertilizer, catfish, Merbau Mataram

\section{Pendahuluan}

Desa Talang Jawa terletak di Kecamatan Merbau Mataram Kabupaten Lampung Selatan dan merupakan kawasan transmigrasi. Desa ini memiliki 10 dusun, salah satunya Dusun Tasik Madu yang terletak dibagian sisi tepi barat dari wilayah desa Talang Jawa yang berbatasan langsung dengan Desa Panca Tunggal. Dusun ini sangat istimewa karena memiliki jumlah kelompok tani terbanyak (3 kelompok tani), yaitu Sumber Rejeki I, Sumber Rejeki II, dan Sumber Rejeki III. Keberadaan 3 kelompok tani di dusun Tasik Madu tersebut merupakan salah satu kebijakan dari Kepala Desa Talang Jawa dengan misi meningkatkan kesejahteraan anggota dan masyarakat sekitar lewat pengembangan bidang pertanian dan peternakan. Pembentukan kelompok tani di dusun Tasik Madu tersebut mewadahi segala aktifitas warga mengingat dusun ini memiliki wilayah terluas.

Beberapa anggota kelompok memiliki kegiatan yang merupakan program produk unggulan kelompok tani yaitu budidaya lele phyton dan budidaya tanaman cabai. Progam Pengabdian Kepada Masyarakat (PKM) DIPA BLU Yunior Universitas Lampung tahun 2017 ini dilakukan melalui kerjasama dengan Kelompok Tani Sumber Rejeki II yang dipilih sebagai mitra karena memiliki status ekonomi dan penghidupan yang lebih rendah.

Hasil analisis situasi dapat diketahui permasalahan yang dihadapi oleh Kelompok Tani Sumber Rejeki II 
di dusun Tasik Madu desa Talang Jawa adalah tidak adanya peningkatan pendapatan warga secara signifikan dari budidaya budidaya tanaman cabai. Hal ini diakibatkan karena warga tidak mempunyai pengetahuan tentang teknik budidaya cabai menggunakan pembuatan pupuk organik cair hasil pemanfaatan limbah peternakan dan limbah organik budidaya lele. Pemanfaatan limbah cair ini membantu warga dengan menurunkan biaya operasional dalam budidaya tanaman cabai [1] sehingga diharapkan mampu memotivasi warga untuk berinovasi dengan ketersediaan limbah yang ada.

\section{Solusi/Teknologi}

Kegiatan Pengabdian Kepada Masyarakat ini dilakukan selama 4 bulan, pada Agustus-November 2016. Khalayak sasaran utama adalah masyarakat dari Kelompok Tani Sumber Rejeki II di Dusun Tasik Madu, Desa Talang Jawa, Kecamatan Merbau
Mataram, Kabupaten Lampung Selatan. Metode pelaksanaan kegiatan dibagi menjadi 3 tahap yaitu: penyuluhan, pelatihan, dan pendampingan, yang dilakukan secara berkala.

\section{Hasil dan Diskusi \\ 1. Penyuluhan}

Kegiatan

penyuluhan dilaksanakan pada hari Jumat, tanggal 25 Agustus 2017 di rumah salah satu warga yaitu Ketua Sumber Mulya Farm, Bapak Muslim. Kegiatan penyuluhan ini dihadiri oleh peserta 12 warga (Gambar 1). Selain pemberian materi yang meliputi teknik pengembangan budidaya tanaman cabai menggunakan fermentasi pupuk organik cair hasil pemanfaatan limbah budidaya lele oleh tim PKM (Gambar 2), juga dilakukan diskusi secara langsung dengan warga mengenai teknik budidaya tanaman cabai menggunakan fermentasi pupuk organik cair tersebut.

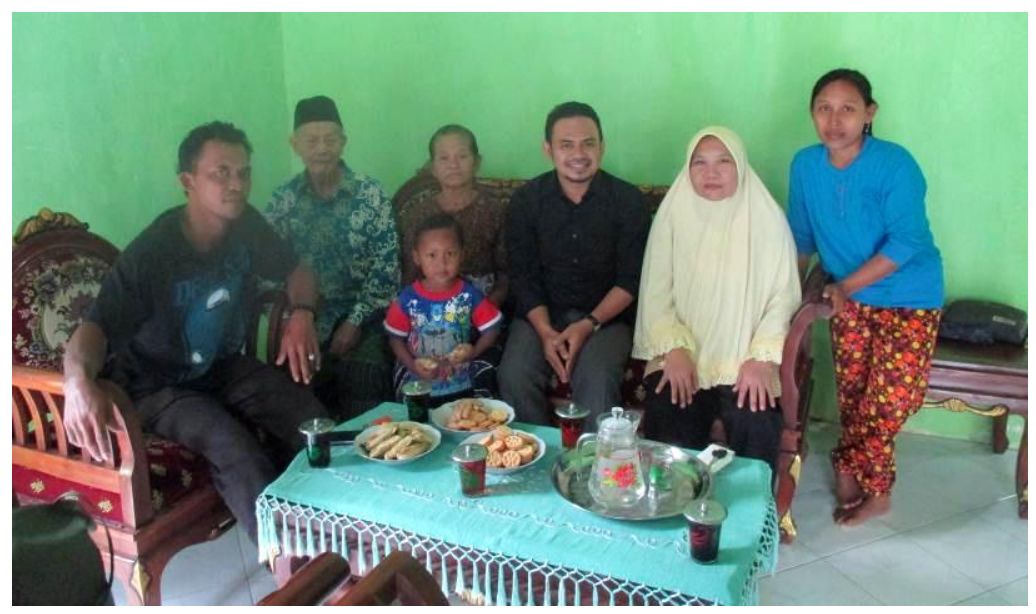

Gambar 1. Penyuluhan pengembangan budidaya tanaman cabai menggunakan fermentasi pupuk organik cair hasil pemanfaatan limbah budidaya lele 


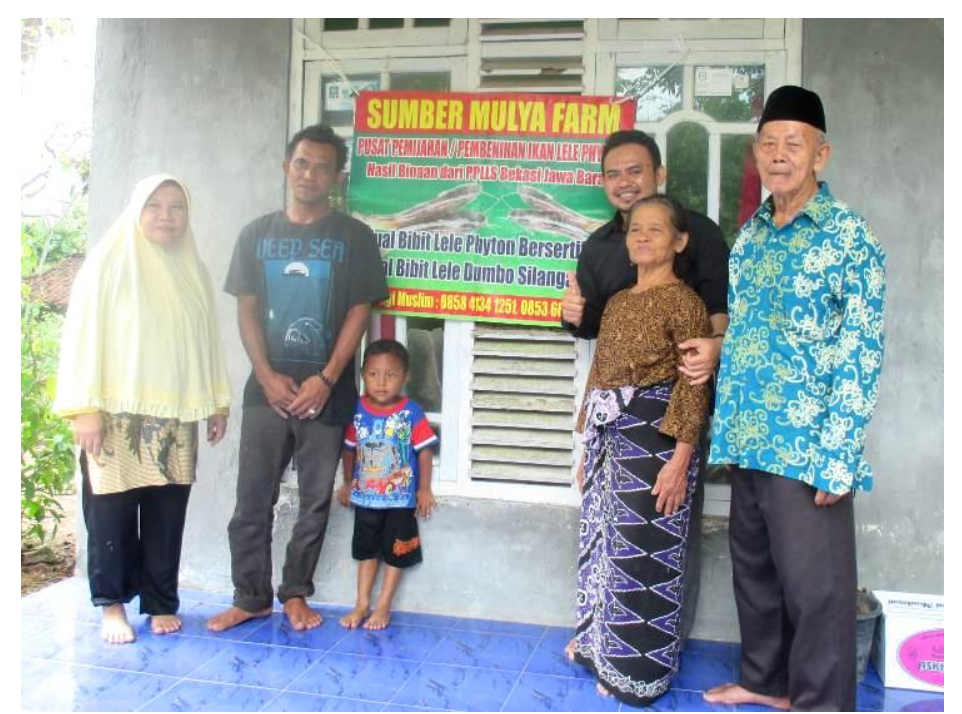

Gambar 2. Kegiatan penyuluhan PKM yang melibatkan mitra yaitu Ketua Sumber Mulya Farm, Bapak Muslim

Acara selanjutnya adalah salah satu mitra dari Sumber Mulya kunjungan ke lapangan tim PKM dan peserta penyuluhan ke lokasi kolam pembudidayaan lele yang merupakan Farm, Bapak Suryanto (Gambar 3 \& 4).

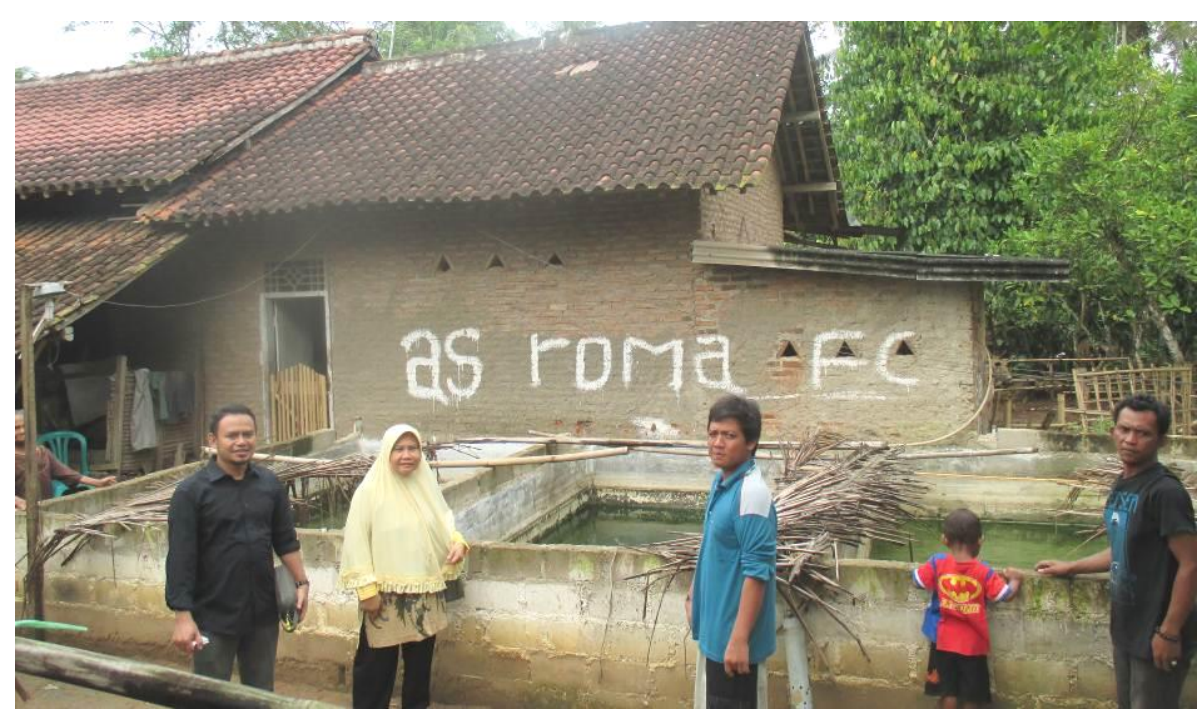

Gambar 3. Kunjungan ke lokasi kolam pembudidayaan lele yang merupakan salah satu mitra dari Sumber Mulya Farm, Bapak Suryanto. 


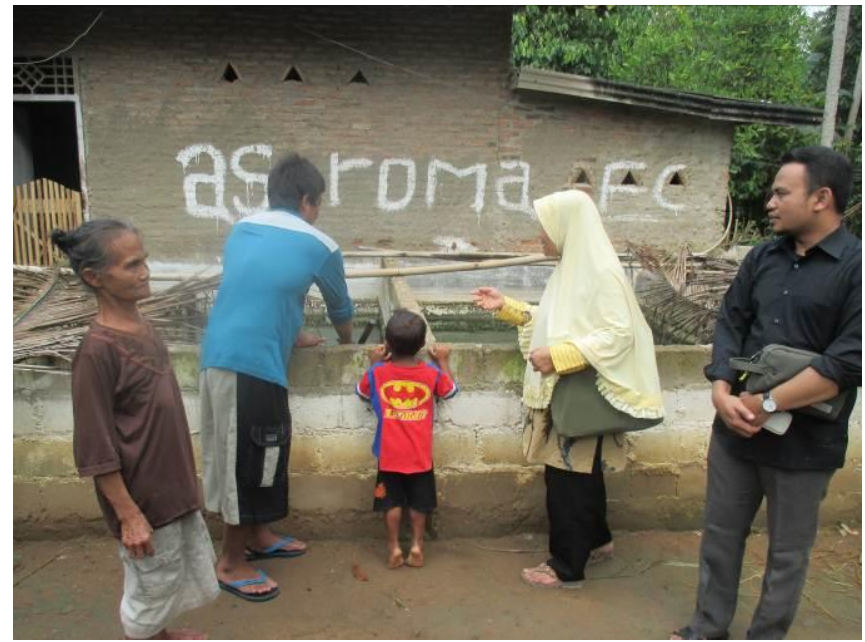

Gambar 4. Kunjungan dan diskusi dengan warga dan pemilik kolam pembudidayaan lele yang merupakan salah satu mitra dari Sumber Mulya Farm, Bapak Suryanto.

\begin{tabular}{lll}
\multicolumn{2}{c}{ Selanjutnya juga dilakukan } & organik cair limbah lele milik Ketua \\
kunjungan ke lokasi pusat \\
pembudidayaan tanaman cabai yang
\end{tabular}$\quad \begin{aligned} & \text { Sumber Mulya Farm, Bapak Muslim } \\
& \text { (Gambar 5). }\end{aligned}$
menggunakan aplikasi fermentasi pupuk
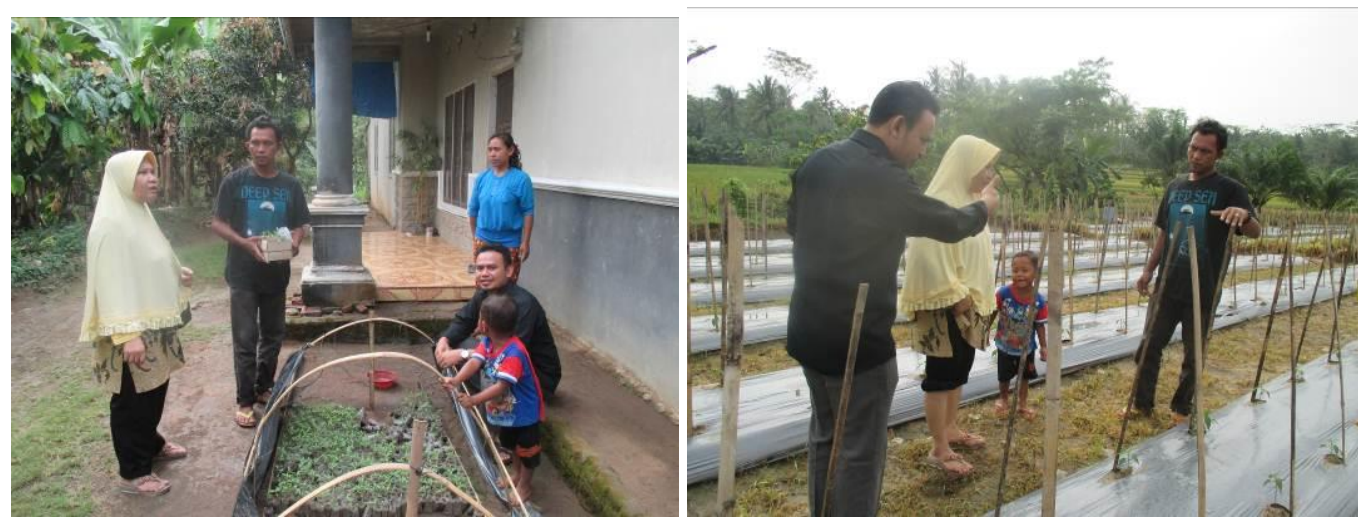

Gambar 5. Kunjungan ke lokasi pusat pembudidayaan tanaman cabai dan diskusi dengan warga dan pemilik pembudidayaan tanaman cabai yang menggunakan aplikasi fermentasi pupuk organik cair limbah lele milik Ketua Sumber Mulya Farm, Bapak Muslim.

Hasil sementara mengenai pengetahuan yang diperoleh peserta diketahui melalui evaluasi terhadap peserta pelatihan. Evaluasi bertujuan untuk mendapatkan masukan yang dapat dijadikan dasar untuk kegiatan lanjutan yang akan dilaksanakan. Secara umum peserta pelatihan banyak yang mengetahui tentang teknik budidaya tanaman cabai, tetapi belum mengetahui teknik pembuatan fermentasi pupuk organik cair hasil pemanfaatan limbah budidaya lele, serta belum mengetahui teknik budidaya tanaman cabai menggunakan fermentasi pupuk organik cair hasil pemanfaatan limbah budidaya lele. Berdasarkan data hasil evaluasi yang diketahui bahwa terjadi peningkatan pengetahuan dan pemahaman peserta pelatihan mengenai pengembangan budidaya tanaman cabai menggunakan fermentasi pupuk organik cair hasil pemanfaatan limbah budidaya lele. 


\section{Pelatihan}

Tahap pelatihan dilakukan dengan kegiatan yang meliputi pengenalan cara budidaya tanaman cabai menggunakan fermentasi pupuk organik cair hasil pemanfaatan limbah budidaya lele yang berlokasi di lahan salah satu warga yaitu Ketua Sumber Mulya Farm, Bapak Muslim (Gambar 7). Pelatihan ini bertujuan agar anggota Kelompok Tani Sumber Rejeki II memiliki kemandirian dalam membudidayakan tanaman cabai menggunakan fermentasi pupuk organik cair hasil pemanfaatan limbah budidaya lele hingga mampu memproduksi buah yang berkualitas. Pelatihan diawali dengan teknik pembuatan fermentasi pupuk organik cair hasil pemanfaatan limbah budidaya lele, selanjutnya dilakukan pelatihan teknik budidaya tanaman cabai menggunakan fermentasi pupuk organik cair hasil pemanfaatan limbah budidaya lele.

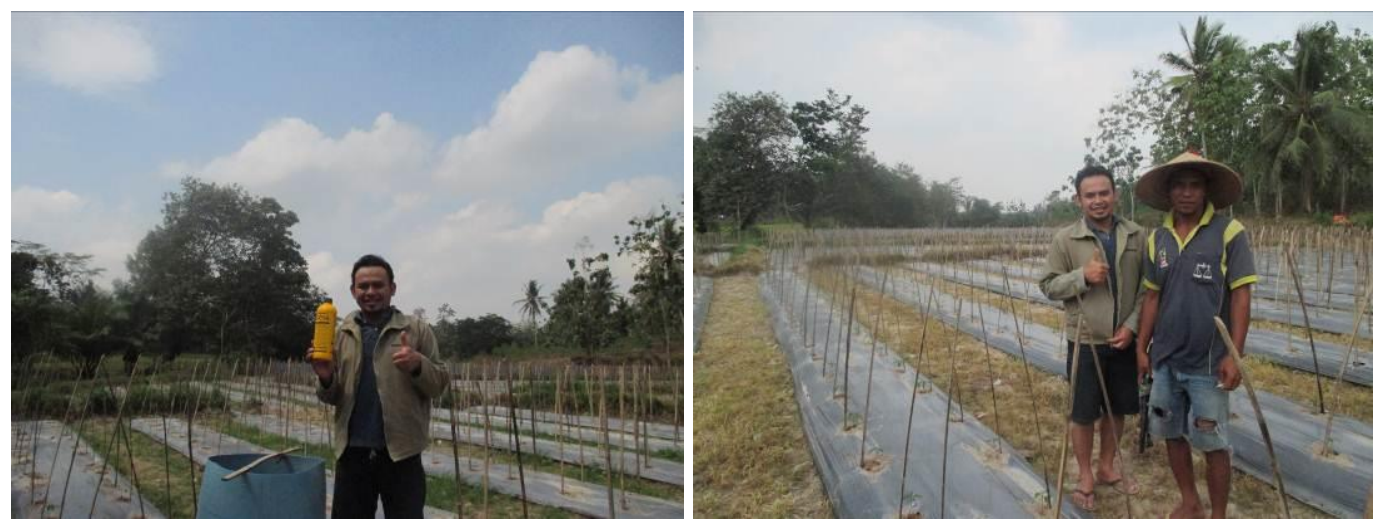

Gambar 7. Tim PKM pada pelatihan pengenalan cara budidaya tanaman cabai menggunakan fermentasi pupuk organik cair hasil pemanfaatan limbah budidaya lele di lahan Ketua Sumber Mulya Farm, Bapak Muslim.

Adapun tahap pembuatan dan aplikasi fermentasi pupuk organik cair hasil pemanfaatan limbah budidaya lele [2]
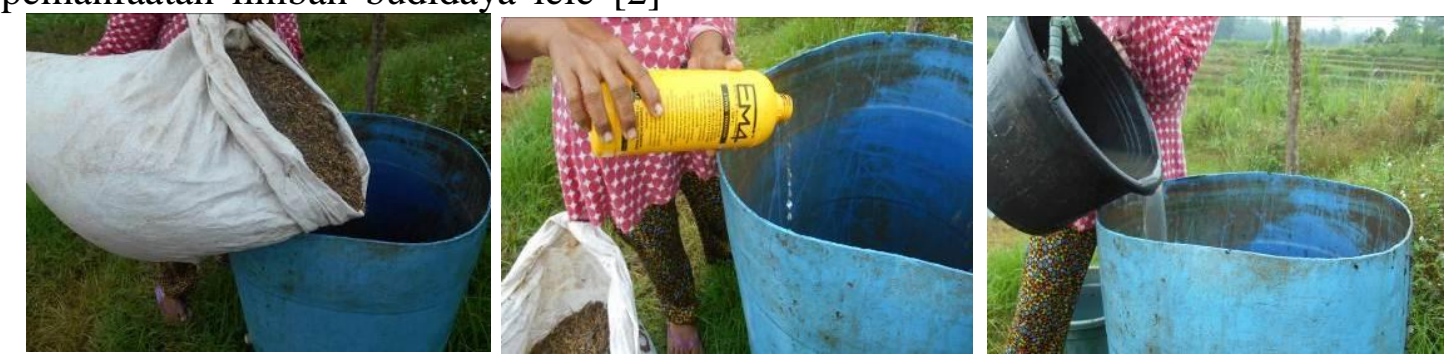

Gambar 8. Kotoran ternak ayam yang telah difermentasi dimasukkan dalam drum (kiri), selanjutnya ditambahkan EM4 (tengah), dan limbah organik air kolam hasil budidaya lele dan air bersih (kanan)

\section{Teknik penyiapan lahan budidaya dan pengairan terintegrasi}

Tanaman cabai membutuhkan ketersediaan air secara berkala. Untuk mencukupi kebutuhan air maka dilakukan teknik pengairan terintegrasi dengan membuat tanggul pada sungai. Hal ini mengingat proses penanaman dapat digambarkan sebagai berikut (Gambar 8). 
sama dalam pengairan tanaman budidaya lain seperti padi dan sayuran [3].

\section{Teknik sterilisasi gulma di sekitar lahan budidaya tanaman cabai}

Saat budidaya tanaman cabai dilakukan pada musim kemarau, sterilisasi gulma di sekitar lahan harus dilakukan. Mengingat gulma tersebut dapat menjadi inang hama dan penyakit bagi tanamaan cabai. Sterilisasi dilakukan dengan radius 10-15 meter dari lahan [7].

\section{Teknik penyemaian dan pembibitan dalam budidaya tanaman cabai}

Mengingat beberapa hama dan penyakit pada tanaman cabai mudah menyebar dan menyerang hampir sepanjang pertumbuhan tanaman, sehingga sebaiknya proses penyemaian dan pembibitan dilakukan jauh dari lahan. Secara umum warga melakukan pembibitan di rumah dengan radius minimal 500 meter dari lahan. Dengan radius yang cukup jauh, hasil pembibitan adalah berupa tanaman cabai sehat yang dapat digunakan selain sebagai bibit tanam utama tetapi juga

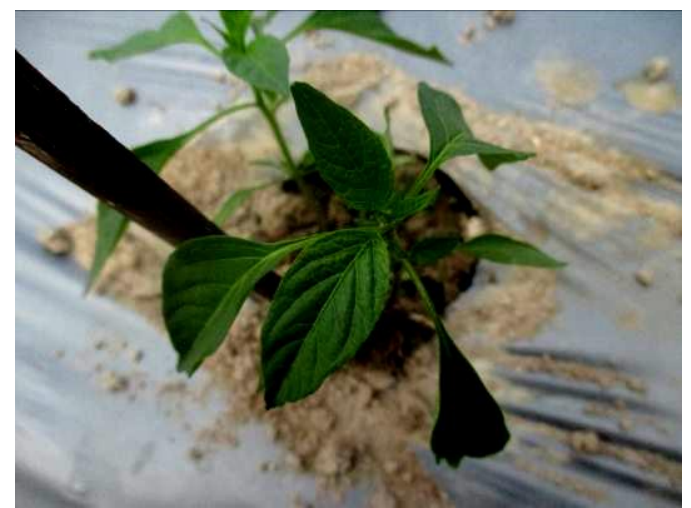

Gambar 9. Pertumbuhan dan perkembangan yang sangat cepat setelah aplikasi fermentasi pupuk organik cair hasil pemanfaatan limbah budidaya lele. Tanaman cabai umur 10 hari setelah tanam (kiri) dan 20 hari setelah tanam (kanan).

untuk sulam pada tanaman cabai yang mati atau terserang penyakit [4][5][6].

\section{Pendampingan}

Proses pendampingan dilakukan sepanjang proses perawatan tanaman cabai dan warga dapat berkonsultasi langsung dengan Ketua Sumber Mulya Farm, Bapak Muslim yang sudah menguasai cara budidaya tanaman cabai maupun tim PKM melalui komunikasi langsung ataupun tidak langsung. Selama pelaksanaan kegiatan dilakukan juga pembekalan, monitoring, dan sekaligus evaluasi keberhasilan kegiatan PKM kepada perwakilan Kelompok Tani Sumber Rejeki II.

Pada tahap kegiatan pendampingan dan evaluasi ini, dapat dilihat hasil kegiatan transfer ilmu kegiatan penyuluhan dan pelatihan yang telah dilakukan sebelumnya yang berpusat pada pusat budidaya tanaman cabai milik Ketua Sumber Mulya Farm, Bapak Muslim. Hasil yang diperoleh adalah beberapa tanaman telah mengalami pertumbuhan dan perkembangan yang sangat cepat setelah aplikasi fermentasi pupuk organik cair hasil pemanfaatan limbah budidaya lele [8] (Gambar 9).

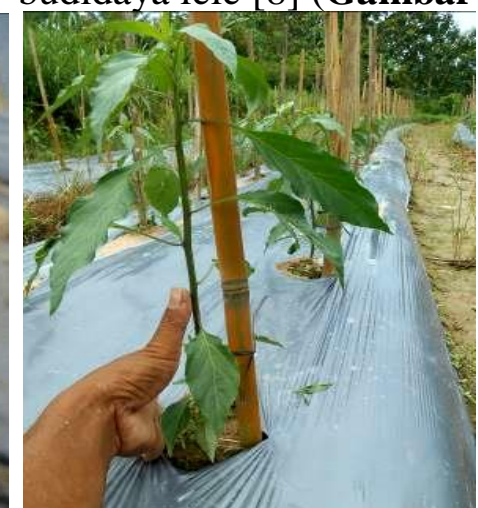

Selama pendampingan dan evaluasi, warga juga sudah aktif mempraktekkan pembuatan fermentasi pupuk organik cair hasil pemanfaatan limbah budidaya lele. Limbah budidaya lele terbaik adalah yang berumur 3 
bulan karena memiliki kadar unsur hara organik dan kepekatan tertinggi

[9][10].(Gambar

10).

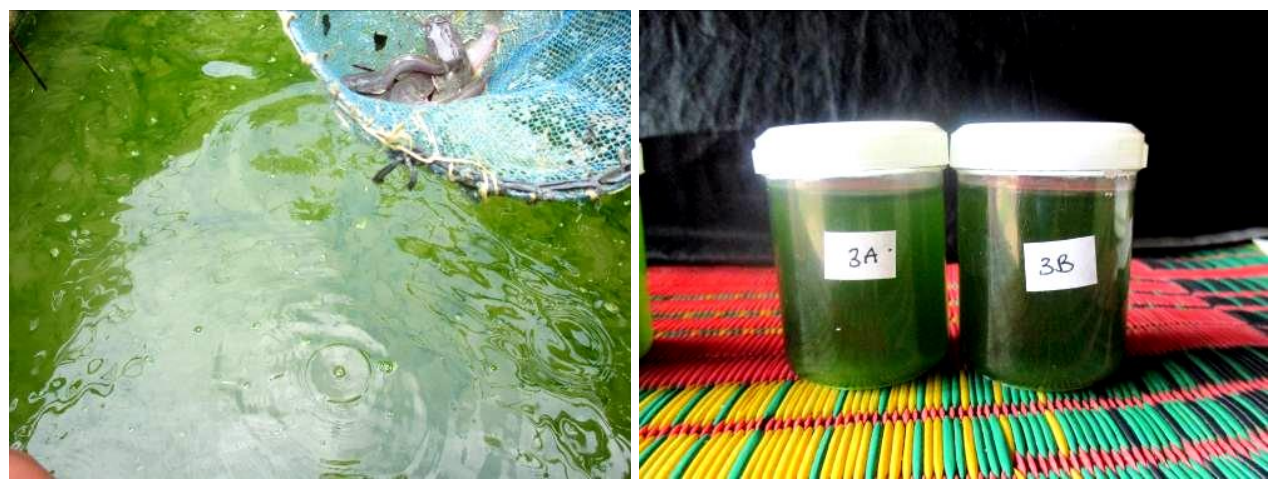

Gambar 10. Kondisi kolam budidaya lele dan penampakan kepekatan air limbah kolam berumur 3 bulan.

\section{Kesimpulan}

Hasil yang diperoleh dalam penyuluhan sebagai kegiatan awal adalah terjadi peningkatan persentase pengetahuan peserta sebelum dan sesudah pelatihan. Warga Kelompok Tani Sumber Rejeki II telah mengalami perubahan paradigma terkait pemanfaatan limbah budidaya lele dalam pembuatan fermentasi pupuk organik cair untuk budidaya tanaman cabai. Warga secara umum telah memahami pembuatan fermentasi pupuk organik cair dengan pemanfaatan limbah budidaya lele serta aplikasinya dalam budidaya tanaman cabai. Dampak positif tidak pemanfaatan limbah cair ini membantu warga dengan menurunkan biaya operasional dalam budidaya tanaman cabai, sehingga diharapkan mampu memotivasi warga untuk berinovasi dengan ketersediaan limbah yang ada. Dengan dukungan penuh warga akan mengalami peningkatan pendapatan warga secara signifikan dari budidaya budidaya tanaman cabai.

\section{Ucapan Terima Kasih}

Pengabdian ini dibiayai oleh DIPA BLU Universitas Lampung, Melalui Surat Keputusan Penetapan Pemenang Hibah Pengabdian Kepada Masyarakat DIPA BLU Universitas
Lampung Tahun 2017 Nomor 935/UN26.21/PM/2017, Tanggal 16 Agustus 2017.

\section{Pustaka}

[1] Andriyeni, F., Nurseha, dan Zulkhasyni. 2017. Studi Potensi Hara Makro Air Limbah Budidaya Lele Sebagai Bahan Baku Pupuk Organik. Jurnal Agroqua. 15(1): 71-75.

[2] Anonim. 2019. Budidaya Cabai. Badan Penelitian dan Pengembangan Pertanian: Kementerian Pertanian. Hal 1-40.

[3] Jafar, MI., Tamrin, MM., dan Zulfiana, IS. 2018. Pemanfaatan Sistem Irigasi Tetes (SIT) Organik Pada Tanaman Cabai Rawit (Capsicum frutescens L.) Di Kelurahan Dembe I, Kecamatan Dembe, Provinsi Gorontalo. Prosiding Seminar Nasional Kolaborasi Pengabdian Kepada Masyarakat 2018. 1(1): 201-205.

[4] Lepongbulan, W., Tiwow, VMA., dan Diah, AWM. 2017. Analisis Unsur Hara Pupuk Organik Cair dari Limbah Ikan Mujair (Oreochromis mosambicus) Danau Lindu dengan Variasi Volume Mikro Organisme Lokal (MOL) Bonggol Pisang. J. Akademika Kim. 6(2): 92-97. 
[5] Prajnanta, F. 2007. Kiat Sukses Bertanam Cabai di Musim Hujan. Penebar Swadaya: Jakarta. Hal 1-88.

[6] Putra, AM. 2017. Pemanfaatan Air Limbah Kolam Ikan Lele Untuk Budidaya Azolla microphylla. Skripsi. Universitas Lampung: Bandar Lampung. Hal 1-46.

[7] Rianto, B., Broto, W., Arifan, F., dan Setyati, WA. 2018. Pengolahan Limbah Hasil Budidaya Ikan Lele Menjadi Pupuk Organik Cair Di Desa Sruwen, Kecamatan Tengaran, Kabupaten Semarang. Prosiding Seminar Nasional Kolaborasi
Pengabdian Kepada Masyarakat 2018. 1(1): 1-2.

[8] Setiadi. 2006. Bertanam Cabai. Penebar Swadaya: Jakarta. Hal 1183.

Tjahjadi, N. 1991. Cabai Seri Budi Daya. Kanisius: Yogyakarta. Hal 147.

[9] Zahroh, F. 2015. Perbandingan Variasi Konsentrasi Pupuk Organik Cair Dari Limbah Ikan Terhadap Pertumbuhan Tanaman Cabai Merah (Capsicum annum L.). Skripsi. Universitas Islam Negeri Walisongo: Semarang. Hal 1-119. 